Mag. Peter

Gabor

Zavod RS za

zaposlovanje

\title{
"ČE ŽELIM, DA BI BILO DRUGAČE, MORAM NEKAJ SPREMENITI« Svetovalna delavnica za (dolgotrajno) brezposelne osebe
}

\section{POVZETEK}

Zdi se, da je prevladujoči pristop h kariernemu in zaposlitvenemu svetovanju v Sloveniji pristop socialne učinkovitosti, za katerega se izkazuje, da je preveč enostranski. Delavnica »Drugače udeležence nagovarja predvsem prek pristopov osebnega razvoja (vključno s konstruktivizmom) in socialnega rekonstruktivizma. Naslanja se na sodobna znanstvena in strokovna dognanja: novejše teorije motivacije, vključitev ustvarjalnosti posameznika v proces kariernega svetovanja, časovne perspektive, kreiranje lastnega življenja, pomen čustev. Udeleženci se je udeležujejo z. veseljem, svetovalci jo radi vodijo. Udeleženci bolje spoznajo sami sebe in naredijo nekatere transformacije v svojih stališčih, doživljanju, prepričanjih in aktivnostih.

Ključne besede: vseživljenjska karierna orientacija, cilji, časovne perspektive, ustvarjalnost, vizualizacija, risanje, smisel življenja, spreminjanje prepričanj, družbenokulturna realnost, kreacija

\section{"IF I WANT IT TO BE DIFFERENT, I MUST CHANGE SOMETHING» ADVISORY WORKSHOP FOR THE (LONG-TERM) UNEMPLOYED CONCEPTUAL FRAMEWORK, DESIGN, AND EFFECTS - ABSTRACT}

The prevailing approach to career and empoyment counselling in Slovenia seems to be the approach aiming at social effectiveness, which is too unilateral. The workshop "Different « addresses the participants mainly through personal development approaches (including constructivism) and social reconstructivism. It relies on contemporary scientific and expert findings: recent motivation theories, inclusion of creativity into the process of carreer counselling, time perspectives, creation of life plan, the meaning of emotions. The participants enjoy the workshop, the counsellors like leading it. The participants come into better contact with themselves and make certain transformations regarding their views, experiences, beliefs and activities.

Keywords: life long career orientation, goals, time perspectives, creativity, visualization, drawing, the purpose of life, changing beliefs, socio-cultural reality, creation

UDK: $374.7: 37.048$

\section{PREDSTAVITEV DELAVNICE}

Krajše poimenovanje delavnice je Drugače. Nastala je v okviru projekta $» V$ seživljenjska karierna orientacija « za iskalce dela in neaktivne na Zavodu RS za zaposlovanje, ki je večinsko financiran iz Evropskega socialnega sklada. Naslov delavnice je, z dovoljenjem avtorice EveGútlinger, prevzet iz knjige Easy:
Mit Leichtigkeit das Abenteuer leben gestalten (2011).

\section{Osnovne informacije}

Program je zasnovan kot svetovalna delavnica, v kateri se prepletajo štirje poglavitni pristopi, tj. kombinacija samoreflektivnih tehnik, različnih vaj in metod za 
samospoznavanje, samopreseganje in trening izbranih veščin, z vseskozi (po potrebi) vključenima kariernim oziroma zaposlitvenim in osebnim svetovanjem.

Poglavitni problem strank in svetovalcev je pogosto nezmožnost za rešitev problema stranke oz. nezmožnost stranke, da ozavesti določene psihične vsebine, ki ji onemogočajo, da bi naredila korak naprej. To drži tudi za svetovanje strankam na zavodu za zaposlovanje. Zaposlitveni, karierni in rehabilitacijski svetovalci se vsi trudijo po najboljših močeh, da bi strankam pomagali premagati ovire, omejujoča prepričanja itd., toda standardni pristop, tj. pogovarjanje, dajanje nasvetov, testiranje, poskusi motiviranja, je, čeprav dobronameren, $v$ nekaterih primerih nezadosten. To še posebej drži za dolgotrajno brezposelne osebe.

Ko je to potrebno, je stranke mogoče nagovoriti tudi na drugačen, dopolnilen način. Te pristope, metode in tehnike je mogoče uporabiti $\mathrm{z}$ namenom opogumljanja strank, da pridejo $\mathrm{v}$ boljši stik same s seboj. Boljši stik s samim seboj posamezniku pomaga pri sprejemanju odločitev in reševanju problemov. Poudarek je na izboljševanju strankinega stika z lastno osebno močjo, pri čemer je svetovalec samo iniciator procesa, skozi katerega je stranka nato zmožna poiskati prave odgovore zase sama pri sebi.

Namen delavnice je dodatno pripomoči k premiku udeležencev od statusa quo, tj. situacije dolgotrajne brezposelnosti, k njenemu razreševanju. Delavnica ni namenjena učenju veščin iskanja zaposlitve, razlagi zakonitosti trga dela ipd.; s tem se ukvarjajo drugi programi in ukrepi. Delavnica je primarno namenjena dolgotrajno brezposelnim, toda primerna je tudi za druge skupine strank.

Cilji delavnice so, da udeleženci pridejo $\mathrm{v}$ boljši stik s samimi seboj; pridejo v boljši stik s svojimi željami in potrebami, kaj bi v življenju radi počeli (v smislu službe oz. zaposlitve); preizprašajo nekatera svoja prepričanja in stališča o svetu, samem sebi in zaposlovanju; spremenijo nekatera svoja prepričanja in stališča o svetu, samem sebi in zaposlovanju; razrešijo nekatere svoje probleme; se mojstrijo v postavljanju ciljev in opredelitvi korakov za njihovo dosego; postanejo bolj proaktivni.

Udeležba na delavnici je prostovoljna. Ravno tako je stvar prostovoljne odločitve vsakega udeleženca, katere vaje in tehnike bo izvajal in katerih ne. Razlogi za to so naslednji: živimo v svetu, katerega temeljni določevalec je svobodna volja; ljudje neradi sprejmemo nekaj, kar nam je vsiljeno; vsakdo od nas ima močno izraženo potrebo po suverenosti in avtonomiji; prostovoljne odločitve v velikem deležu speljemo do konca, neprostovoljnih pogosto ne; delavnica je po vsebinski in pristopni plati drugačna od ustaljenih oblik dela z brezposelnimi osebami.

Tudi za svetovalce je odločitev za izvajanje delavnice prostovoljna. Razlogi so enaki navedenim zgoraj.

Potek in trajanje: 1. vsebinsko pisno vabilo na predstavitev delavnice; 2 . predstavitev delavnice potencialnim udeležencem; 3 . pet srečanj v trajanju (po) okoli dve uri enkrat ali dvakrat na teden.

\section{TEORETIČNA IN IZKUSTVENA IZHODIŠčA}

\section{Štirje pristopi h karierni orientaciji in/ali zaposlitvenemu svetovanju}

Na področju karierne in zaposlitvene orientacije obstajajo štirje pristopi oz. konceptualni okviri. »Prvi pristop je pristop socialne 
učinkovitosti: matching, ponudba in povpraševanje na trgu dela, socialne potrebe oz. potrebe družbe, realizem, posredovanje na delovna mesta, pristop kompetenc. Drugi pristop je razvojni: samouresničenje posameznika, izbire posameznika, konstruktivistični pristopi, pristopi pripovedovanja zgodb. Tretji konceptualni okvir je pristop socialnega rekonstruktivizma: dekodiranje družbenega, kritična, reflektivna praksa, strukturalni pristopi. Četrti pristop je akademski: statusna orientacija, ekspertni modeli, modeli, temelječi na raziskavah.« (Sultana, 2012)

Logiko šole socialne učinkovitosti dobro poznamo, saj jo v bistvu - vsaj na deklarativni ravni (praksa je bolj življenjska, saj drugače preprosto ne gre) - uporabljamo v večinskem delu. Upravičena je ocena, da je domet tega vpogleda, pristopa in metode omejen. Predvsem zato, ker je v svojih konceptualnih okvirih glede na kompleksnost življenja in področja kariere ter zaposlovanja močno redukcionistična.

Vsak pristop poudarja en vidik karierne in zaposlitvene realnosti. Šele skupaj tvorijo celoto.

Kot kaže, je najboljši pristop h kariernemu in zaposlitvenemu svetovanju tisti, ki do določene mere upošteva poglede vseh štirih konceptualnih okvirov.

Delavnica je zasnovana kot dopolnilni pristop k uveljavljenemu večinskemu pristopu socialne učinkovitosti, in sicer $\mathrm{z}$ vidikov preostalih treh šol: nekaj malega s področja akademskega pristopa, nekaj več s področja socialnega rekonstruktivizma in največ s področja razvojnega pristopa in konstruktivizma.

\section{Teorija motivacije za današnji čas}

Človekov svet se spreminja. Spreminja se paradigma, naš pogled na svet in na nas same. Spreminjamo se tudi mi. Stari načini delovanja izgubljajo svojo moč, pojavljajo se novi načini.

Vedno bolj jasno postaja, da so stari načini motiviranja ljudi oz. prepričanja glede motivacije deloma preživeti. Model motiviranja »korenček in palica« ne dosega več rezultatov, ki jih je dosegal še do prek kratkim. Raziskovalci človeške motivacije ugotavljajo, da nagrada (denar - pod predpostavko, da posameznik zasluži dovolj za normalno preživetje) in kazen oz. neugodje, povzročeno od zunaj, nista več tista, ki bi ljudi najbolj spodbujala k dejavnosti (Pink, 2011; Miller in Rollnick, 2002).

\section{Kaj nas najbolj motivira}

Trije dejavniki, ki ljudi najbolj motivirajo $\mathrm{k}$ dejavnosti, so:

- avtonomija - ljudje delajo najbolj motivirano, če jim je omogočena zadostna mera avtonomije glede tega, kaj bodo počeli, in tudi glede tega, kako in kdaj bodo to počeli;

- mojstrstvo - ljudje se radi urijo oz. postajajo vedno boljši v tem, kar delajo;

- $\quad$ življenjski namen - ljudje delajo motivirano, če opravljajo tisto delo, ki je v skladu z njihovim življenjskim namenom, tj. če v svojem delu najdejo širši smisel, če delajo za širši cilj (Pink, 2011).

\section{Karierno/zaposlitveno svetovanje in osebno svetovanje}

Kariernega svetovanja ni mogoče ločiti od osebnega. 
»Imbimbo (1994) piše, da sta bili karierno oz. zaposlitveno svetovanje in osebno svetovanje vedno videni kot dve ločeni področji svetovalnih praks. Problem takšnega pogleda je $\mathrm{v}$ tem, da pogosto ignorira tudi ugotovitve dolgoletne tradicije na področju kariernega svetovanja, ki prepoznava velik pomen osebnostnih dejavnikov posameznika pri odločanju in sledenju svoji karierni poti. Verjame v to, da 'mora' biti svetovalec zmožen prehajati med aktivno in direktivno vlogo kariernega oz. zaposlitvenega svetovalca in spodbujevalno ter raziskovalno vlogo osebnega svetovalca'.«(Liptak, 2005: 174)

Videnje, da sta karierno oz.zaposlitveno svetovanje in osebno svetovanje medsebojno neodvisni in izključujoči se področji oz. da ljudje lahko ločijo svoje osebne zadeve od tega, kar se dogaja $\mathrm{v}$ njihovem poklicnem življenju, je neutemeljeno poenostavljanje.

\section{Kreacija oz. kreiranje lastnega življenja}

Dosedanje znanstveno videnje sveta, v katerem živimo, je bilo videnje, da je svet neodziven sistem, na katerega ljudje nimamo nobenega vpliva. To je videnje opazovalca. Novejše, tudi znanstveno videnje je diametralno nasprotno od tega. Mogoče ga je poimenovati kot videnje udeleženca (Braden, 2010).

McTaggartova v knjigi Polje: po sledeh nevidnih sil v vesolju navaja, da je v zadnjih 40 letih skupina raziskovalcev $\mathrm{z}$ različnih področij tako teoretično kot tudi eksperimentalno utemeljevala, da je jedro našega vesolja valujoče morje energije, eno samo ogromno kvantno polje (McTaggart, 2004).Del tega polja smo tudi živa bitja. Tudi ljudje: »[...] na naši najbolj temeljni ravni smo živa bitja, vključno z ljudmi, skupki kvantne energije, ki nenehno izmenjuje informacije s tem neizčrpnim morjem energije (Mc Taggart, 2004: 56). »Če to drži,potem je vse povezano z vsem ostalim, kot nekakšna nevidna mreža. (Mc Taggart, 2004: 25) Model vesolja, ki ga v zadnjem času orisujejo raziskovalci, je »model vesolja, ki je do določene mere pod našo upravo. Naše želje in namere ustvarjajo našo resničnost.« (McTaggart, 2004: 208) Gregg Braden je to »ogromno kvantno polje« poimenoval božanska matrika; »[...] kvantna teorija in starodavna besedila implicirajo, da na nevidnih ravneh ustvarjamo načrte za odnose, kariere, uspehe in neuspehe v vidnem svetu. $\mathrm{S}$ te perspektive božanska matrika deluje kot ogromen kozmični zaslon, ki nam omogoča videti nefizično energijo naših čustev in prepričanj (našo jezo, sovraštvo in bes ter tudi našo ljubezen, sočutje in razumevanje), ki se projicirajo $\mathrm{v}$ fizičnem mediju življenja.«(Braden, 2010: 14)

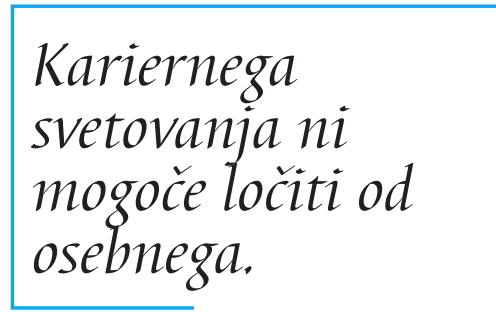

Načrte ustvarjamo tudi za »kariere, uspehe in neuspehe«. Kozmos se odziva na človekove akcije, dejanja, misli, občutke, čustva, zavedno in nezavedno, racionalno in iracionalno.

Tako na neomejujoče misli, čustva, zavedno in nezavedno kot tudi na omejujoče misli, čustva, zavedno in nezavedno.

\section{Družbenokulturni sistem in posameznik oz. zunanji in notranji dejavniki, ki vplivajo na odločitve posameznikov}

Poglavitna ugotovitev antropologije je, da ljudje primarno živimo $v$ t. i. kulturni realnosti. To pomeni, da na svet in sebe gledamo na način, za katerega kultura in družba pravita, da je resničen in pravi. Vemo, vidimo, občutimo, spoznavamo in poznamo predvsem tisto, 
kar nam kultura, v katero se rodimo, dovoli videti. Bolj ali manj. Živimo in vedemo se ter dojemamo na način, kot nam ga predpiše kultura, v katero se rodimo. Bolj ali manj.

Družbenokulturni sistem, kakršen je, ni niti slučajno najboljši možen, ni pošten, ni dober za vse. Sili nas v marsikaj, kar za nas ni dobro, koristno, česar si ne želimo početi. To postaja vse bolj jasno vedno večjemu številu ljudi. Vedno bolj jasno vedno večjemu številu ljudi postaja tudi to, da družbenokulturni sistem ni »od boga dan« in da je kot tak spremenljiv.

Družbenokulturni sistem z vsemi podsistemi (politični, religiozni, monetarno-ekonomski, gospodarski, zdravstveni itd.) omejuje osebno moč posameznika. To dosega predvsem z nenehnimu stvarjanjem strahu. Strah pa je »matična plošča« za vse, kar označujemo z besedo negativno. Negativno pa ustvarja negativno. Ni treba, da bi bilo tako.

Kapitalistični sistem, v katerem trenutno živimo, je npr. narejen tako, da nikoli nimajo službe vsi delovno sposobni ljudje. Nikoli niso zaposleni vsi, ki bi lahko delali. To je eden izmed načinov vzdrževanja visoke ravni negotovosti in strahu v družbi. Poglavitni razlog za situacijo brezposelnosti tako na ravni družbe oz. sistema kot tudi na ravni posameznika je povezan z osebno močjo posameznika. Sistem onemogoča oz. poskuša onemogočati moč posameznika, ker to ustreza določenemu segmentu ljudi. Po drugi strani pa nas ta isti sistem izdatno obremenjuje $\mathrm{z}$ individualnim občutkom krivde, ker da smo za svojo življenjsko situacijo v polni meri odgovorni sami. Kar obenem ni in je res. Ni res zato, ker smo svojo moč predali v roke temu sistemu, ki to želi doseči od nas, in je tako nimamo več. Res pa je zato, ker je moč, ki smo jo predali v roke nekomu zunaj nas, pravzaprav naša moč. To moč lahko kadarkoli vzamemo nazaj.
To, da ima vsakdo med nami osebno moč za kreiranje lastnega življenja, pa vsekakor ne pomeni - karikirano rečeno -, da smo vsi zmožni ali da si vsi želimo ustanoviti s.p. Nismo vsi rojeni za samostojne podjetnike. To pomeni, da smo zmožni s »sevanjem, ki ga oddajamo v svet «, do določene mere sokreirati tudi delovno mesto oz. zaposlitev zase. Stvar dodatno zaplete še antropološko in sociološko dejstvo, da družbo, v katero se rodimo in ki nas $\mathrm{v}$ precejšnji meri oblikuje, $\mathrm{s}$ tem, kako razmišljamo in kaj počnemo, tudi soustvarjamo. Mikro soustvarjamo. Toda to soustvarjanje je zaradi naše »programiranosti« v precejšnji meri lahko zgolj vzdrževanje sistema takšnega, kot je. Zaradi te kompleksnosti oz. prepletene dvojno dvojne igre družbenokulturnega sistema in nas smo vsi do določene mere izgubljeni in pošteno zmedeni. Tudi večina politikov. Obenem pa na nas vse (na politike, delodajalce in posameznike) trenutno vpliva še spreminjanje vsesplošne paradigme. Svet se spreminja in posledično se spreminja naš pogled na svet. In/ali obratno. Zdi se, da je gospodarska kriza eden izmed vidikov teh sprememb.

Zdi se, da se svet spreminja iz življenja večinoma $\mathrm{v}$ bolečini $\mathrm{v}$ smer življenja večinoma $\mathrm{v}$ radosti in smer rahljanja institucionalnih okvirov ipd., pri čemer pa se stare oblike družbenokulturnega bojujejo za svoj obstanek tako, da svoje rešitve, načine delovanja in poglede še intenzivirajo. To trenje povzroča velike dodatne napetosti, ki jih občutimo mi vsi. Med drugimi najbolj tudi ljudje, ki so ostali brez zaposlitve oz. ne dobijo zaposlitve, kakršno bi si želeli.

Del teh napetosti je tudi precejšnja nejasnost glede tega, kam gremo oz. kam bi želeli iti kot posamezniki in kot družba. Nejasnost in posledični strah je pogojen $\mathrm{s}$ tem, da smo sredi procesa. Stare oblike se še niso poslovile, 
potrebne nove rešitve pa še niso jasne. Na nas vplivajo zunanji in notranji dejavniki. Na nas ne vplivajo samo zunanji dejavniki, kot smo bili večinoma naučeni verjeti. Obenem pa ni vse v našem življenju odvisno popolnoma od nas samih. Bi bilo, če bi nam družbenokulturni okvir to dovoljeval oz. dopuščal. Ampak nam ne. Vsaj za zdaj še ne.

\section{Ambivalenca}

Ljudje želimo razrešiti nezaželeno situacijo, v kateri smo se znašli, pri čemer pa nas ima veliko težave $\mathrm{z}$ antagonistično motivacijo. Radi bi naredili spremembo, toda pri tem nas ovirajo slabe izkušnje iz preteklosti, omejujoča prepričanja, zavračanje in pa to, da ob odločitvi za novo vedno izgubimo nekaj starega. Zelo povedna je etimološka razlaga besede odločitev; v prvi vrsti gre pri vsaki odločitvi za od-ločitev, za ločitev od starega, znanega, udobnega, za ločitev od tistega $\mathrm{v}$ trenutni situaciji, kar mi nekaj (takšnega ali drugačnega) prinaša.

\section{Strategije odločanja}

Strategijo odločanja in reševanja problemov lahko razdelimo na dva pristopa: na kognitivne metode odločanja (npr. metoda plusov in minusov) in na intuitivno odločanje (Amundson, 2009).

Vedno bolj jasno je, da odločanje poteka tako na iracionalni kot na racionalni ravni; odločanje je vedno celostno. Ljudje se nikoli ne odločamo samo racionalno (kot trdijo nekatere starejše teorije), vedno je v odločitev vpleten tudi del iracionalnega, npr. intuicija, občutki ipd., pri čemer ima vsakdo lahko povsem svoj pogled na to, kaj je racionalna in primerna odločitev. »Dober občutek glede odločitve je lahko ključen dejavnik v procesu odločanja.« (Amundson, 2009: 235)
Spodnja tretjina »jajca biti« predstavlja podzavest, srednja tretjina zavest, zavestno, zgornja tretjina pa nadzavest, nadjaz oz. višji jaz. Meje med temi tremi deli osebnosti oz. uma so prehodne, meja med »jajcem biti (posameznikom) in okoljem je prehodna, tako podzavest kot nadzavest sta $\mathrm{v}$ veliki meri nezavedni, tudi vseh vsebin zavesti nimamo ves čas v aktivni zavesti (Parfitt, 1997).

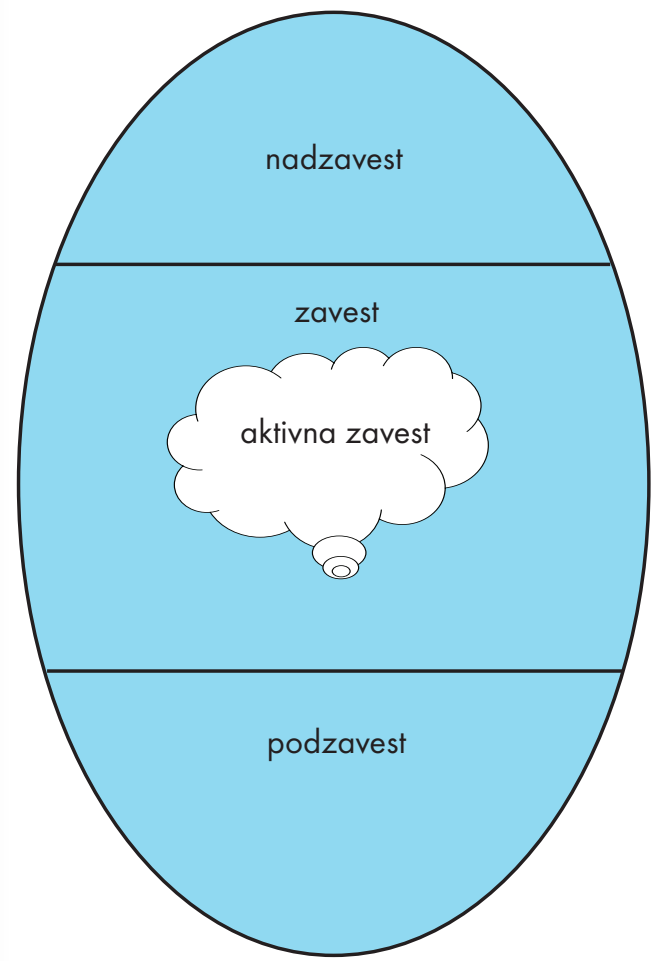

Slika 1 : »Jajce biti« oz. ravni zavesti (vir: Parfitt, 1997)

Nadzavest oz. višji jaz je »prostor navdiha, področje ustvarjalnosti in velike lepote ter plemenitih idej « (Meadows, 2003: 79-80). V nadzavesti so tudi rešitve in viri za reševanje problemov. Nadzavedne vsebine so zavesti dosegljive prek meditacije, glasbe, (terapevtskih) pogovorov, občutkov ter z nekaterimi metodami, ki jih je mogoče označiti s terminom umetniške tehnike. Vsi ti načini vzpostavijo most med nadzavednim in zavednim. 
Ustvarjalni proces kot pomoč pri samospoznavanju in reševanju problemov

Projektivne tehnike in metode so zelo dobrodošle pri delu na sebi in delu s strankami. Poglavitni razlog za njihovo uporabnost je $\mathrm{v}$ tem, da se ljudje marsičesa, kar zadeva nas same, naš odnos do samih sebe, odnos do sveta in ljudi okoli nas, preprosto ne zavedamo. Za to je več razlogov: 1. sami sebe ne vidimo od zunaj, ampak se gledamo od znotraj, zaradi česar ima lahko naš pogled na samega sebe precej slepih peg; 2 . iz takšnih ali drugačnih razlogov se nekaterih stvari preprosto ne želimo zavedati (bolečina, obrambni mehanizmi itd.); 3. nadaljnji razlog za koristnost projektivnih tehnik in metod, ki je tesno povezan z navedenima, je ta, da ljudje uvide, spoznanja, razjasnitve o samem sebi, do katerih se dokopljemo sami, običajno bolje sprejmemo in upoštevamo - v nasprotju z neprijetnimi informacijami o nas samih, ki jih dobimo od soljudi, na katere se ponavadi odzovemo $\mathrm{z}$ odporom in trmo.

Komunikacija s samim seboj in reševanje problemov se lahko zgodita tudi na napol nezavedni ravni, pri čemer ustvarjalni proces služi kot močna pogonska sila. Sproščena ustvarjalna energija običajno služi kot koristen vir za reševanje svetovalnih problemov, bodisi neposredno bodisi posredno. Primeri ustvarjalnih procesov so npr.: risanje, pesnjenje, pisanje in pripovedovanje zgodb, uporaba metafor, uporaba telesa (Amundson, 2009).

$\mathrm{S}$ pomočjo samoprojekcijskih in imaginacijskih tehnik ter metod lahko posameznik pride do nekaterih odgovorov samemu sebi o samem sebi in reši nekatere probleme oz. nezaželene situacije.

\section{Risanje}

Risanje je zelo močna in uporabna ustvarjalna samoprojekcijska tehnika. Slika pove več kot tisoč besed, rečemo; ko rišemo, rišemo tudi vsebine, ki jih težko ubesedimo. Ko rišemo, smo v večjem/tesnejšem stiku s samim seboj, tudi z nezavednimi deli nas samih, kot takrat, ko (samo) govorimo.

\section{Pripovedovanje zgodb}

Ljudje smo bazično zgodbarski. Pripovedovanje in poslušanje zgodb je v naši krvi.

Vsi imamo potrebo, da se naša zgodba sliši. Šele ko neki dogodek iz svojega življenja ali svojo življenjsko zgodbo povemo sočloveku, se ta izkušnja dokončno vkomponira $\mathrm{v}$ nas; dokler ne povemo drugemu, izkušeno na neki način ni trdno oz. še ne čisto resnično.

Ljudje znanja, vedenja in informacije, ki so vkodirane $\mathrm{v}$ zgodbe, prenašamo in osvajamo sorazmerno lahko. Prek zgodb (lahko) tudi navdihujemo druge, jih opogumljamo ali razbremenjujemo.

S pripovedovanjem zgodb tudi ozaveščamo vzorce, po katerih delujemo. Pogosto na podlagi pripovedovanja zgodb iz svojega življenja pripovedovalec doživi aha trenutek; šele ko pripoveduje, se lahko zave, kaj počne, kako deluje, kakšne so nekatere njegove predpostavke, ki vplivajo na njegovo življenje. Ta učinek bi lahko poimenovali učinek »ko povem, se zavem«.

Zaupanje življenjskih in delovnih izkušenj svetovalca svetovancu ni prepovedano, ampak je celo zelo dobrodošlo. V ozadju tega dejanja se skriva močan človeški oz. intermotivacijski naboj, ki lahko precej pripomore k svetovančevemu uspešnejšemu spoprijemanju $\mathrm{z}$ odločitvami, ki so pred njim - v generičnem smislu. Verjetnost, da se bo svetovanec odločal oz. ravnal tako, kot se je odločal oz. ravnal svetovalec, je majhna. Vsakdo med nami je edinstven. Vsakdo odločitve na koncu sprejema po sebi, pri tem pa nam je lahko $\mathrm{v}$ 
precejšnjo pomoč prenos izkušenj, motivacije in poguma s podelitvijo zgodbe.

\section{Spraševanje in diskutiranje}

Ljudje smo odnosna bitja. Zaradi tega potrebujemo dialoško orientirano komunikacijo.

»Možgani delujejo na način, da ko jim je zastavljeno vprašanje, avtomatično in aktivno začnejo iskati odgovor nanj.«(Gütlinger, 2011)

\section{Čustva}

Čustva so sestavni del človeka. Niso manj pomembna od razuma.

»Novejše raziskave, tudi na področju biologije oz. fiziologije, poudarjajo pomembnost sodelovanja in medsebojne soodvisnosti med razumom in čustvom. Kot pravi Daniel Goleman v Čustveni inteligenci: ,Ideal stare paradigme je bil razum, osvobojen vpliva čustev. Nova paradigma nas sili, da uskladimo glavo in srce." « (Wilks, 2009)

Čustva so potrebna oz. opravljajo določene funkcije, zaradi česar jih je treba upoštevati tudi pri svetovalnem delu. Čustveni vidik je (tudi) v procesih odločanja izjemno pomemben dejavnik, precej bolj, kot smo bili pripravljeni priznati še pred kratkim. Zgolj racionalistični modeli odločanja se poslavljajo, ker ne izražajo realnega stanja, kaj vse ljudje smo. V našem življenju imajo zelo pomembno - in deloma še vedno skrivnostno - vlogo čustva, občutki in intuicija.

\section{Čustva in zaposlovanje}

»Teoretiki in deloma tudi praktiki kariernega/ zaposlitvenega svetovanja iz svojih posploševanj pogosto izpustijo čustveni del odločanja, kar je gromozanska redukcionistična napaka.« (Ruppert, 2010b) »V svetovalnem procesu je treba upoštevati, da med čustvi in kognicijo obstaja intenzivna korespondenca. Svetovalci moramo v odnosu do svetovancev uporabljati tako imenovano kognitivno empatijo; kognitivno empatijo je po vsej verjetnosti mogoče označiti za ključno kompetenco za svetovalce.«(Ruppert, 2010c)

\section{Čustva in motivacija ter obravnava čustev}

Čustva so tudi bistveni, konstituirajoči del motivacije. Pravzaprav je med čustvi in motivacijo težko potegniti ločnico. Čustva in/ali motivacija so pomemben gibalec ali zaviralec določenega vedenja. V prvi vrsti se vsi precej odločamo na podlagi čustev, tako prijetnih (radost, prijetno vznemirjenje, pričakovanje, veselje, optimizem) kot neprijetnih (strah, negotovost, slabe izkušnje, nezaupanje).

Čustva so prinašalci sporočil. Ko posameznik popolnoma ozavesti, katero čustvo trenutno doživlja in zakaj ga doživlja, ga nato lažje sprejme (tudi s pomočjo podporne klime); v trenutku, ko ga sprejme (in sporočilo, ki ga čustvo prinaša), pa slednje nenadoma izgubi svojo intenziteto. Intenzivnost čustva upade vsaj za polovico. Posledično je, še zlasti ob doživljanju intenzivnih t.i. negativnih čustev, videnje trenutne situacije jasnejše, jasnejše je nato tudi odločanje.

S spraševanjem udeležencev o njihovem čustvenem doživljanju slednje v nekem smislu priznamo in prepoznamo kot celostne osebe. Obenem pa jim s tem pomagamo obvladovati njihova čustva. Svetovalci lahko svetovancem zastavimo dve ključni vprašanji: 1 . Katera čustva trenutno doživljaš oz. katera čustva si doživljal?, 2. Zakaj mislišs, da doživljaš oz. si doživljal ta čustva? Kaj misliš, da ti sporočajo?

\section{Pozitivna čustva vs. negativna čustva}

Vse na delavnici uporabljene vaje in metode (risanje, vodena vizualizacija, trening postavljanja ciljev in določanja korakov 
za njihovo doseganje itd. ) so zasnovane tako, da posameznik, ki jih izvaja, ne podleže negativnim občutjem. V največjem delu komunicira s svojim nadjazom. Tu so doma samo t.i. pozitivna čustva in občutja. Udeleženci poročajo o doživljanju občutkov miru, umirjenosti, radosti, igrivosti, svobode.

\section{Imaginacija oz. vodena vizualizacija}

Imaginacija resnično deluje in ima opazen vpliv na življenje in okoliščine posameznika. Tudi v psihologiji je to že dolgo znano. Najverjetnejši odgovor na vprašanje, zakaj dejansko učinkuje, je združena razlaga, da prek zavestne oz. nezavedne obdelave vsebin in/ali prek bazične energetske narave sveta (teorija kvantnega polja) z imaginacijo in vizualizacijo posameznik zavestno vpliva na svojo zavest in posledično na svoje nezavedno, kar se posledično manifestira $\mathrm{v}$ njegovi materialni realnosti. V nekem smislu so imaginacija tudi risanje vsebin iz življenja posameznika, pripovedovanje zgodb ipd.

\section{Zelo uspešni ljudje se zavedajo svoje- ga poslanstva.}

\section{Smisel življenja oz. življenjsko poslanstvo \\ Vsakdo od nas je edinstven. Vsakdo od nas ima tudi svoj edinstveni življenjski smisel. Življenjski smisel oz. življenj-} ska poklicanost je pri vsakomur od nas najbolj temeljno gibalo. Če svoje življenje gradimo na podlagi te motivacije, se počutimo izpolnjene in koristne.

»Zelo uspešni ljudje nimajo samo ciljev, ampak se zavedajo svojega poslanstva, svoje poklicanosti, imajo svoj vodilni življenjski cilj. Ti ljudje niso nujno bolj nadarjeni, bolj inteligentni ali prodorni, ni nujno, da imajo močnejšo voljo ali da so rojeni pod srečnejšo zvezdo kot drugi. Pomembneje je, da jim je vsa njihova stremljenja in moči uspelo usmeriti $\mathrm{v}$ en sam cilj, prav to pa je tisto, kar označuje poslanstvo. Gre za součinek vseh vrednot, prepričanj, interesov, želja in ciljev nekega človeka. Občutek poslanstva vliva človeku vztrajno občutenje življenjskega cilja, krepi njegovo identiteto, odločnost, budi strast in navdušenje." (Schwarz in Schweppe, 2005: 41)

Precejšen del življenjskega smisla posameznika, če ne celo najpomembnejši, je tudi njegov poklicni smisel.

Veliko ljudi svojega življenjskega poslanstva nima ozaveščenega. »Večina ljudi je brez ... vodilnega življenjskega cilja, nima poslanstva. Imajo poklic, delo, službo - to, kar morajo početi, delati - in imajo zasebno življenje, v katerem skušajo početi to, kar si v resnici želijo, da bi uresničili svoje vrednote.« (Schwarz, Schweppe, 2005: 41)

Veliko ljudi se tudi za poklic oz. kariero odloča predvsem na podlagi strahov, izmed katerih je običajno najmočneje izražen strah za preživetje, ne pa na podlagi svojega življenjskega smisla. Zato jih izbire, ki jih v življenju naredijo, ne zadovoljujejo, ne radostijo in ne osrečujejo. Odločajo se na podlagi bolečine in ne na podlagi radosti. Svoje življenje ustvarjajo iz bolečine, ne iz radosti.

To, da posameznik sledi svojemu življenjskemu smislu in ga živi, je seveda dobro zanj. Toda ni dobro samo zanj; koristi od njegovega dela, strasti, radosti, navdušenja, rezultatov, stvaritev imamo mi vsi. Težko si je zamišljati svet brez, npr., Alberta Einsteina, Nelsona Mandele, natakarice $\mathrm{v}$ sosednjem baru ali svetovalca na zavodu. Vsakdo od nas zase in tudi za širšo družbo opravlja nujno potrebno funkcijo. 


\section{Časovna orientiranost}

Ljudje svoja življenja živimo časovno orientirani. Na kontinuumu preteklost-sedanjostprihodnost pa smo lahko različno orientirani. Zimbardo in Boyd (2009) razločujeta pet časovnih usmeritev: znotraj preteklosti negativno in pozitivno preteklost, znotraj sedanjosti hedonistično in fatalistično sedanjost ter prihodnost.

Od tega, kakšen je posameznikov časovni profil, sta odvisna način in posledično kakovost življenja, ki ga živi. Optimalni časovni profil po Zimbardu in Boydu (2009) vključuje naslednja razmerja: visoko na perspektivi pozitivna preteklost, zmerno visoko na perspektivi prihodnost, zmerno visoko na perspektivi hedonistična sedanjost, nizko na perspektivi negativna preteklost in nizko na perspektivi fatalistična sedanjost.

Določen del prebivalstva je zasidran bodisi v negativni preteklosti, pretirano hedonistični sedanjosti, bodisi fatalistični sedanjosti. Ljudje, ki živijo v teh časovnih orientacijah, praviloma niso $\mathrm{v}$ zadostni meri orientirani na prihodnost. Ti ljudje nimajo kognitivnih shem, ki bi jim govorile, da je za to, da bi nekaj dosegli, potrebno nekaj narediti. Primerna orientacija na prihodnost pomeni med drugim tudi orientacijo $\mathrm{v}$ trud in delo.

Drugi razlog, ki je po vsej verjetnosti samo druga plat zgoraj navedenega, ki jih zavira in onemogoča, je ta, da je njihova motivacija $v$ bistvu zajezena s psihičnimi oz. energetskimi blokadami. Te energetske blokade so čustvene narave. Poimenujemo jih lahko energetski vozli in običajno so to strahovi, razočaranje, zamere, jeza, sovraštvo itd.
Kako lahko pristopimo $k$ posameznikom, $k i$ so ujeti $v$ negativni preteklosti in pretirano hedonistični in/ali fatalistični sedanjosti

Obstaja več metod, načinov ali posredovanj, s katerimi lahko deloma popravimo navedene časovne fiksacije. To so večinoma zadeve, ki jih lahko oz. mora narediti vsak posameznik sam, če se odloči, da bi rad spremenil svoj časovni profil in posledično popravil svoj način življenja. Pri nekaterih spremembah posamezniku lahko pomagajo (psiho)terapevti.

Nekaj pa lahko naredimo tudi svetovalci. Brezposelnim osebam lahko pomagamo, da se naučijo postavljati cilje in opredeljevati korake, ki jih je treba narediti, da bodo zastavljene cilje dosegli. Zimbardo in Boyd (2009) sta opravila eksperiment $\mathrm{z}$ učenci, ki so bili zelo nizko na perspektivi prihodnosti tudi zaradi navedenih časovnih fiksacij. Trenirala sta jih v postavljanju ciljev, ki jih želijo doseči v prihodnosti, ter $\mathrm{v}$ določanju posameznih korakov za dosego teh ciljev. Trening sta začela s postavljanjem ciljev najprej za današnji dan, nato za jutri, nato za teden dni in za mesec dni. Rezultati so bili opogumljajoči, udeleženi učenci so se po enem tednu navedenega treninga v opazni meri usmerili v prihodnost. Naučili so se, da če želijo kaj doseči, morajo za to tudi nekaj narediti. Deloma so se naučili tudi osredotočenosti na posamezen korak oz. osredotočenosti na korakanje, kar jim je odvzelo pogosto hromečo potrebo, da bi bil njihov cilj dosežen že danes.

\section{STRUKTURA OZ. VSEBINA DELAVNICE}

Predstavitev delavnice potencialnim udeležencem pred njihovo odločitvijo za vključitev.

Prvo srečanje: sprejem udeležencev; odpravljanje (trenutne) antagonistične motivacije 
oz. umirjanje s pomočjo tehnike PEAT (Slavinski, 2009); pisanje/risanje lastne knjige življenja (Amundson, 2009);predstavitev moderatorja; predstavitev udeležencev oz. pripovedovanje življenjskih zgodb oz. ustna predstavitev napisane knjige življenja; povzemanje vseh predstavitev.

Drugo srečanje: pogovor o doživljanju na prejšnjem srečanju in $\mathrm{v}$ času med srečanjema; zunanji in notranji dejavniki, ki vplivajo na nas in naše življenje; zunanji dejavniki, ki vplivajo na nas in naše življenje; notranji dejavniki, ki vplivajo na nas in naše življenje; trening postavljanja ciljev in korakov za doseganje teh ciljev (v roku enega dneva) (Zimbardo in Boyd, 2009); imaginacija/vizualizacija; vodena vizualizacija spreminjanja notranjih slik (reševanje problemov) (Gútlinger, 2011).

Tretje srečanje: pogovor o doživljanju na prejšnjem srečanju in v času med srečanjema; časovna orientacija; pomemben je vsak korak na poti do cilja; kreacija lastne realnosti; moč prepričanj in čustev, ki jih gojim (McTaggart, 2004; Braden 2010; Gútlinger, 2011); ozaveščanje prepričanj, ki jih gojimo o svetu; ozaveščanje prepričanj, ki jih gojimo o sebi; ozaveščanje prepričanj, ki jih gojimo o zaposlovanju; sedem korakov za doseganje ciljev (McGraw, 2002); trening postavljanja ciljev in korakov za doseganje teh ciljev (v roku enega tedna) (Zimbardo in Boyd, 2009); vodena vizualizacija spreminjanja notranjih slik (reševanje problemov) (Gûtlinger, 2011).

Četrto srečanje: pogovor o doživljanju na prejšnjem srečanju in $\mathrm{v}$ času med srečanjema; kreiranje pozitivnih/manj omejujočih prepričanj o svetu; kreiranje pozitivnih/ manj omejujočih prepričanj o sebi; kreiranje pozitivnih/manj omejujočih prepričanj o zaposlovanju; risanje splošnega smisla življenja oz. mojega splošnega življenjskega poslanstva; trening postavljanja ciljev in korakov za doseganje teh ciljev ( $\mathrm{v}$ roku enega meseca) (Zimbardo in Boyd, 2009); vodena vizualizacija spreminjanja notranjih slik (reševanje problemov) (Gûtlinger, 2011).

Peto srečanje: pogovor o doživljanju na prejšnjem srečanju in $\mathrm{v}$ času med srečanjema; risanje poklicnega/zaposlitvenega smisla življenja; zavzeto delovanje in akcije; trening postavljanja ciljev in korakov za doseganje teh ciljev (v roku enega leta) (Zimbardo in Boyd, 2009); vodena vizualizacija spreminjanja notranjih slik (reševanje problemov) (Gútlinger, 2011); čudežno vprašanje glede zaposlitve; zaključek delavnice.

\section{Dosedanje izvedbe delavnice}

Avtor delavnice Drugače je v prvi polovici leta 2012 imel dve demonstracijski izvedbi. V aprilu 2012 so bili karierni in zaposlitveni svetovalci povabljeni $\mathrm{k}$ usposabljanju za izvajanje delavnice. Odločitev za udeležbo na usposabljanju in kasnejše izvajanje delavnice je bila prostovoljna. Usposabljanja v maju 2012, ki je trajalo dva dni, se je udeležilo devet svetovalcev iz devetih različnih uradov za delo. Ti moderatorji so delavnice prvič izvedli v obdobju od julija do oktobra 2012.

\section{Analiza dosedanjih izvedb delavnice}

Povratne informacije udeležencev so bile (večinoma) zbrane v obliki esejskih zapisov.

Povratne informacije moderatorjev so bile zbrane $\mathrm{v}$ obliki esejskih zapisov in $\mathrm{v}$ pogovoru na srečanju po prvih izvedbah delavnice. 


\section{Podatki o izvedbah}

\section{Udeležba}

Delež dolgotrajno brezposelnih oseb (DBO), ki so se odzvale na vabilo in prišle na predstavitveno srečanje, je velik - slabih 85 odstotkov (A). Delež oseb, ki so prišle na predstavitveno srečanje in se nato odločile za udeležbo na delavnici, je prav tako velik 83 odstotkov (D). Delež oseb, ki so se izmed vseh vabljenih na predstavitev odločile za redno obiskovanje srečanj, je sorazmerno velik - dobrih 70 odstotkov (B). Deleži oseb, ki so se odzvale na vse tri vrste vabil (A, D in B), so - še posebej glede na to, da so bile vse odločitve prostovoljne - veliki. Delež oseb, ki so izmed vseh vabljenih na predstavitveno srečanje delavnico nato redno obiskovale, je sorazmerno velik - slabih 68 odstotkov (C). Delež tistih, ki so po odločitvi, da bodo delavnico obiskovali, to tudi redno počeli, je zelo velik - 96 odstotkov (E).

Zato lahko sklepamo, da je delavnica za potencialne udeležence zelo zanimiva in da ima prostovoljnost udeležbe oz. avtonomnost odločanja velik učinek. ${ }^{1}$

\section{Struktura udeležencev po spolu}

Velika večina dolgotrajno brezposelnih (DBO) in brezposelnih oseb (BO), ki so se odločile za vključitev v delavnico, je ženskega spola. Podatek ne preseneča, saj je skladen z dolgoletnimi izkušnjami. Za delavnice in tudi druge

Tabela 1: Udeležba

\begin{tabular}{|c|c|c|c|c|}
\hline & $\begin{array}{l}\text { Število DBO, } \\
\text { vablienih na } \\
\text { predstavitveno } \\
\text { srečanje }\end{array}$ & $\begin{array}{l}\text { Št. DBO, ki } \\
\text { so se odzvali } \\
\text { vabilu in prišli na } \\
\text { predstavitveno } \\
\text { srečanje }\end{array}$ & $\begin{array}{l}\text { Št. DBO, ki so } \\
\text { se odločili, da } \\
\text { bodo delavnico } \\
\text { obiskovali }\end{array}$ & $\begin{array}{l}\text { Število DBO, } \\
\text { ki so delavnico } \\
\text { redno (večinsko) } \\
\text { obiskovali }\end{array}$ \\
\hline Število udeležencev & 105 & 89 & 74 & 71 \\
\hline $\begin{array}{l}\text { Delež tistih, ki so od } \\
\text { vseh vablienih: } \\
\text { (A) prišli na predstavit- } \\
\text { veno srečanje; } \\
\text { (B) se odločili, da bodo } \\
\text { delavnico obiskovali; } \\
\text { (C) delavnico redno } \\
\text { obiskovali }\end{array}$ & & $\begin{array}{l}(\mathrm{A}) \\
84,8 \%\end{array}$ & $\begin{array}{l}\text { (B) } \\
70,5 \%\end{array}$ & $\begin{array}{l}\text { (C) } \\
67,6 \%\end{array}$ \\
\hline $\begin{array}{l}\text { Delež tistih, ki so se po } \\
\text { udeležbi na predstavit- } \\
\text { venem srečanju odloči- } \\
\text { li, da bodo delavnico } \\
\text { obiskovali }\end{array}$ & & & $\begin{array}{l}\text { (D) } \\
83 \%\end{array}$ & \\
\hline $\begin{array}{l}\text { Delež tistih, ki so po } \\
\text { odločitvi, da bodo } \\
\text { delavnico obiskovali, to } \\
\text { tudi redno počeli }\end{array}$ & & & & $\begin{array}{l}(E) \\
96 \%\end{array}$ \\
\hline
\end{tabular}


Tabela 2: Struktura udeležencev po spolu

\begin{tabular}{|l|l|l|l|}
\hline Spol & Moški & Ženske & Skupai \\
\hline Frekvenca & 9 & 62 & 71 \\
\hline Delež & $12,7 \%$ & $87,3 \%$ & \\
\hline
\end{tabular}

oblike dejavnosti, tudi tiste za delo na sebi, se - ne samo na zavodu - večinoma odločajo ženske. Moški svoje težave rešujejo drugače.

\section{Starostna struktura udeležencev}

Polovica udeležencev delavnice je stara od 30 do 39 let. Delavnice so se udeležili tudi mlajši in starejši, tudi starejši od 50 let. Iz starostne skupine do 20 let ni bilo nobenega udeleženca; v tej starostni skupini zaradi vključenosti

Tabela 3: Starostna struktura udeležencev

\begin{tabular}{|l|l|l|l|l|l|l|}
\hline Starostni razredi & do 20 let & 20 do 29 let & 30 do 39 let & 40 do 49 let & 50 let in več & Skupaj \\
\hline Frekvenca & 0 & 17 & 35 & 14 & 5 & 71 \\
\hline Delež & $0 \%$ & $23,9 \%$ & $49,3 \%$ & $9,7 \%$ & $7 \%$ & \\
\hline
\end{tabular}

v srednješolsko in visokošolsko izobraževanje skorajda ni dolgotrajno brezposelnih oseb.

Na podlagi zbranih povratnih informacij moderatorjev in udeležencev je mogoče ugotoviti, da je delavnica Drugače primerna za udeležence vseh starosti.

\section{Izobrazbena struktura udeležencev}

Delavnice so se udeležile osebe vseh izobrazbenih stopenj, pri čemer prevladujejo (slaba polovica) osebe s V. izobrazbeno stopnjo.

Tabela 4: Izobrazbena struktura udeležencev
$\mathrm{Na}$ podlagi zbranih povratnih informacij moderatorjev in udeležencev je mogoče ugotoviti, da je delavnica Drugače načeloma primerna za udeležence vseh izobrazbenih stopenj.

\section{Struktura udeležencev glede na čas prija-} vljenosti na zavodu

Delavnice so se večinoma udeležile dolgotrajno brezposelne osebe (DBO), nekatere pa po statistiki zavoda niso bile dolgotrajno brezposelne (čas prijavljenosti na zavodu do enega leta), takih je bilo okoli 23 odstotkov.

Delavnice so se večinoma udeležile DBO, prijavljene na zavodu od enega leta do štirih let (67 odstotkov). Delavnice so se udeležile

\begin{tabular}{|l|l|l|l|l|l|l|l|}
\hline $\begin{array}{l}\text { Stopnja } \\
\text { izobraz- } \\
\text { be }\end{array}$ & $\begin{array}{l}\text { I. + II. } \\
\text { (OŠ ali } \\
\text { manj) }\end{array}$ & $\begin{array}{l}\text { III. } \\
\text { (nižja po- } \\
\text { klicna šola) }\end{array}$ & $\begin{array}{l}\text { IV. } \\
\text { (srednja } \\
\text { poklicna } \\
\text { šola) }\end{array}$ & $\begin{array}{l}\text { V. } \\
\text { (srednja } \\
\text { strokovna } \\
\text { šola ali gim- } \\
\text { nazija) }\end{array}$ & $\begin{array}{l}\text { VI. } \\
\text { (višja šola) }\end{array}$ & $\begin{array}{l}\text { VII. } \\
\text { (visoka } \\
\text { šola ali } \\
\text { več) }\end{array}$ & Skupaj \\
\hline Frekvenca & 4 & 1 & 9 & 33 & 11 & 13 & 71 \\
\hline Delež & $5,6 \%$ & $1,4 \%$ & $12,7 \%$ & $46,5 \%$ & $15,5 \%$ & $18,3 \%$ & \\
\hline
\end{tabular}

tudi DBO, prijavljene na zavodu dlje kot štiri leta (okoli 10 odstotkov).

Na podlagi zbranih povratnih informacij moderatorjev in udeležencev je mogoče ugotoviti, da je delavnica Drugače načeloma primerna tako za DBO in $\mathrm{BO}$ ne glede na čas prijavljenosti na zavodu.

\section{Doživljanja in mnenja udeležencev - skupni poudarki}

Mnenje je dalo 58 udeležencev od 71 .

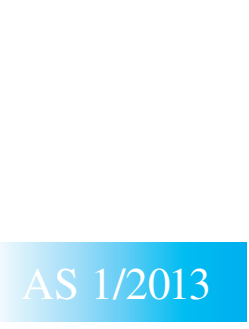


Tabela 5: Struktura udeležencev glede na čas prijavljenosti na zavodu

\begin{tabular}{|l|l|l|l|l|l|l|l|l|l|l|l|}
\hline $\begin{array}{l}\text { Čas prijavlienosti } \\
\text { na zavodu }\end{array}$ & $\begin{array}{l}0-1 \\
\text { leta }\end{array}$ & $\begin{array}{l}1-2 \\
\text { leti }\end{array}$ & $2-3$ leta & $\begin{array}{l}3-4 \\
\text { leta }\end{array}$ & $\begin{array}{l}4-5 \\
\text { let }\end{array}$ & $\begin{array}{l}5-6 \\
\text { let }\end{array}$ & $\begin{array}{l}6-7 \\
\text { let }\end{array}$ & $\begin{array}{l}7-8 \\
\text { let }\end{array}$ & $\begin{array}{l}8-9 \\
\text { let }\end{array}$ & $9-10$ let & Skupai \\
\hline Frekvenca & 16 & 18 & 22 & 7 & 0 & 4 & 0 & 2 & 1 & 1 & 71 \\
\hline Delež & $22,5 \%$ & $25,4 \%$ & $31 \%$ & $9,9 \%$ & $0 \%$ & $5,6 \%$ & $0 \%$ & $2,8 \%$ & $1,4 \%$ & $1,4 \%$ & \\
\hline
\end{tabular}

Doživljanja udeležencev in njihova mnenja o delavnici je mogoče strniti takole:

- delavnica je zelo dobro ali celo odlično sprejeta; velika večina udeležencev jo je ocenila v pozitivnem smislu:

- »Delavnica se je dotaknila vseh nas, udeležencev in svetovalke, saj smo vseskozi govorili o življenju; kako ga ovrednotiti, osmisliti; o sebi, kaj delam prav, kaj lahko naredim bolje, kaj vse je še neizkoriščeno, kdo sem, kje sem, zakaj sem.«

- delavnico ocenjujejo kot potrebno:

- $\quad \gg$ To potrebujemo.«

- $\quad$ Delavnica je koristna.«

- $\quad$ Dotaknil se me je predvsem sproščen in igriv pristop skozi procese, za katere nas družba kot odrasle ljudi sili, da jih pozabimo.«

- »Delavnica je dobra tudi zato, ker smo marsikaj naredili na sebi.«

- »Nekaj novega, drugačnega, vsebina povsem nova in spodbuja razmišljanje.«

- udeležencem je bil še posebno všeč sproščen način vodenja:

- zaradi katerega so se odprli in tudi bolje sprejemali vsebine in vaje

- všeč jim je to, da je delavnica »sproščena in $»$ svobodna

- na srečanja so hodili z veseljem in v prijetnem pričakovanju

- dobro počutje
- $\quad$ udeleženci so v veliki meri zadovoljni s konceptom/vsebinami/uporabljenimi vajami, metodami in tehnikami:

- sprejeli so jih brez težav in zdijo se jim učinkoviti

- udeleženci niso imeli težav z nobeno vsebino, tehniko, vajo

- vsebine, vaje in metode se jim zdijo zanimive in koristne ter učinkovite

- posebej so poudarili, da so na delavnici dobili možnost govoriti o sebi, izražati svoja mnenja in se pogovarjati med seboj ter $\mathrm{z}$ moderatorjem:

- zelo pomemben vidik delavnice - v polni meri pozivno sprejet - je »druženje $\ll$

- $\quad$ Spoznaš, da v tej situaciji brezposelnosti nisi sam.«

- $\quad$ \Spoznaš zanimive ljudi.«

- »Izmenjavanje mnenj, izkušenj, informacij.«

- $\quad$ zavedeli so se oz. začeli so se zavedati nekaterih »novih stvari«:

- tako individualno (glede sebe) kot tudi širše (glede družbe) gledano

- vsebine jim odpirajo »doslej zastrta oz. zaprta obzorja in perspektive«:

- »Zavedela sem se novih stvari.«

- »Še nikoli nisem veliko razmišljal o sebi na takšen način.«

- udeleženci se $\mathrm{v}$ nekem smislu prebudijo; dogajajo se jim premiki, delajo premike: 
- premike v doživljanju, stališčih, odnosih od situacije brezposelnosti, v kateri so se znašli

- na individualni ravni/ravni doživljanja posameznikov se je udeležencem dogajalo:

- boljše poznavanje samega sebe

- ozaveščanje nekaterih stvari pri sebi

- prepoznavanje tega, kaj bi bilo pri sebi dobro spremeniti

- udeleženci naredijo »korak naprej«

- ozavestijo osebnostne zavore na poti do zaposlitve:

- udeležencem se dvigne raven življenjske energije

- postanejo ustvarjalnejši

- postanejo odgovornejši

- postanejo proaktivnejši

- postanejo bolj razmišljujoči in načrtno usmerjeni

- $\quad$ vsi moderatorji so vrhunski:

- so visoko strokovni

- do udeležencev imajo »odnos enakovrednosti, enakopravnosti «, ki udeležencem dodatno pomaga pri odločanju za premike

\section{Doživljanja in mnenja moderatorjev o delavnici - skupni poudarki}

Doživljanja moderatorjev in njihova mnenja o delavnici je mogoče strniti takole:

- prostovoljnost udeležbe je prava stvar:

- $\quad$ Ni nobene prisile, sodelujejo pa vsi.«

- »Udeleženci so bili motivirani in so zelo dobro sodelovali.«

- „Vsi so radi prihajali na srečanja.«

- delavnica je med udeleženci dobro sprejeta: tev delavnice.«

- $\quad$ ॥deleženci jo dobro sprejemajo.«

- $\mathrm{z}$ nobeno od vsebin/tehnik/metod udeleženci niso imeli težav

- delavnica je načeloma primerna za udeležence vseh izobrazbenih stopenj in vseh starosti

- $\quad$ skupine udeležencev so dobro (so)delovale:

- »Udeleženci so svoja mnenja izražali brez problemov.«

- $\gg \mathrm{V}$ okviru skupine so se odpirala nova vprašanja in dileme, ki smo jih skupaj reševali oz. prišli do uvida. «

- $\quad$ Skupine so se med seboj zelo povezale, izmenjavale so izkušnje in se spodbujale.«

- delavnica je potrebna:

- »Menim, da je delavnica zelo primerna za delo z brezposelnimi osebami, še posebno $\mathrm{v}$ trenutni situaciji na trgu dela, ko je veliko negotovosti in stisk ter ko ljudje potrebujejo intenzivno podporo pri doživljanju in preživljanju situacije brezposelnosti.«

- $\quad$ »Meni se zdi delavnica Drugače pozitiven odziv na situacijo, ki postaja vse bolj pereča. S tem mislim na BO, ki nam ostajajo na zavodu dalj časa in za njih nimamo ustreznih programov, orodij, da bi jim pomagali.«

- $\quad$ Trg dela se je v zadnjih letih drastično spremenil in z njim tudi pojmovanje kariere, ki zahteva nenehno delo na sebi. Delavnica Drugače je za marsikoga prvi resen korak k temu.«

- udeleženci bolje spoznajo samega sebe, naredijo premike, spremenijo nekatera prepričanja in stališča:

- $\quad$ Udeleženci so se prepustili odkrivanju samih sebe, svojih želja, talentov in ovir.« 
- $\quad$ Prišli so do spoznanja, da kljub negotovi situaciji in nespornim oviram lahko naredijo premike v svojem razmišljanju in dejanjih. Delavnico so zaključili z optimistično naravnanostjo.«

- »Presenetljivo hitro in dobro so ozavestili svoje življenjsko poslanstvo in zaposlitveni smisel življenja.«

- $\quad$ Nekateri so ugotovili, da so v svojem življenju opustili načrtovanje, da so se enostavno sprijaznili, pozabili na želje.«

- »Doseženo je bilo aktiviranje in motiviranje udeležencev pri načrtovanju nadaljnje karierne poti.«

\section{Učinki delavnice - aktivacija/izhodi udeležencev}

Spodaj opisano »dogajanje « z udeleženci delavnice prikazuje stanje s konca decembra 2012, to je nekaj mesecev po delavnici.

Večina udeležencev se je skozi delavnico aktivirala za reševanje situacije brezposelnosti; ne samo aktivirala, ampak so to energijo aktivacije/ motiviranosti v precejšnjem številu tudi manifestirali oz. konkretizirali. Pri tem je treba poudariti, da je velika večina tistih, ki so se aktivirali, konkretne odločitve sprejela že na delavnici oz. $\mathrm{v}$ prvem ali pa najkasneje drugem mesecu po izteku delavnice.

V tabelo je vključena tudi ena oseba, ki se je prijavila na delavnico, ampak je ni redno obiskovala. Nekateri udeleženci (14) so se aktivirali dvojno (dve aktivnosti); v tabeli zgoraj je zanje zabeležena samo po ena (primarna oz. »vidnejša ) aktivacija. Dobrih 15 odstotkov udeležencev se je zaposlilo (tako redno kot prek javnih del) (A). Slabih sedem odstotkov udeležencev se je vključilo v druge (ne javna dela) ukrepe aktivne politike zaposlovanje (APZ) (B). Slabih 17 odstotkov udeležencev se je odločilo, da bi se radi vključili v različne ukrepe APZ (̌̌e ni uresničeno). Šestindvajset odstotkov udeležencev intenzivno išče zaposlitev. Za vključitev v šolanje oz. dokončanje šolanja se je odločilo dobrih osem odstotkov udeležencev. Slabih šest odstotkov se jih je odločilo za vključitve v tečaje. Slabih šest odstotkov jih je registriralo osebno dopolnilno delo.

Seveda ni možno vseh aktivacij udeležencev pripisati samo učinkovanju delavnice. Dejavnikov, ki pri posamezniku vplivajo na odločitve in posledično na delovanje, je veliko (spol, starost, življenjske izkušnje, izobrazba, prepričanja, čustva, pričakovanja, vpliv okolja, vključno s politično-gospodarskimi razmerami in družinskim stanjem itd.). Natančno določiti, kateri dejavnik ali pa sklop dejavnikov vpliva na to, da posameznik nekaj stori, je težko.

Glede na to, da so udeleženci navedene aktivnosti izvedli oz. jih izvajajo po udeležbi na delavnici in da so bili v delavnico vključeni pretežno dolgotrajno brezposelni, ki precej časa niso zmogli sprejeti odločitve oz. narediti koraka naprej na poti reševanja svoje situacije brezposelnosti, se zdi sklep, da je k njihovi aktivaciji precej pripomogla delavnica, kar sprejemljiv.

Za zavod je najbolj objektivno merilo uspešnosti ukrepov, ki jih izvajamo, podatek o tem, koliko ljudi se po izvedbi ukrepa zaposli. Podatek o tem, kolikšen delež od vseh udeležencev delavnice se je po delavnici bodisi zaposlil (slabih 10 odstotkov), bodisi zaposlil prek javnih del (slabih šest odstotkov, skupaj s prejšnjo kategorijo 15,3 odstotka, A), bodisi vključil v druge ukrepe APZ (slabih sedem odstotkov) - skupni delež je 22 odstotkov (B) -, lahko razumemo kot objektivno merilo uspešnosti delavnice. Delež ni majhen, še posebno glede na to, da gre večinoma za DBO. Za šolanje, 
Tabela 6: Učinki delavnice

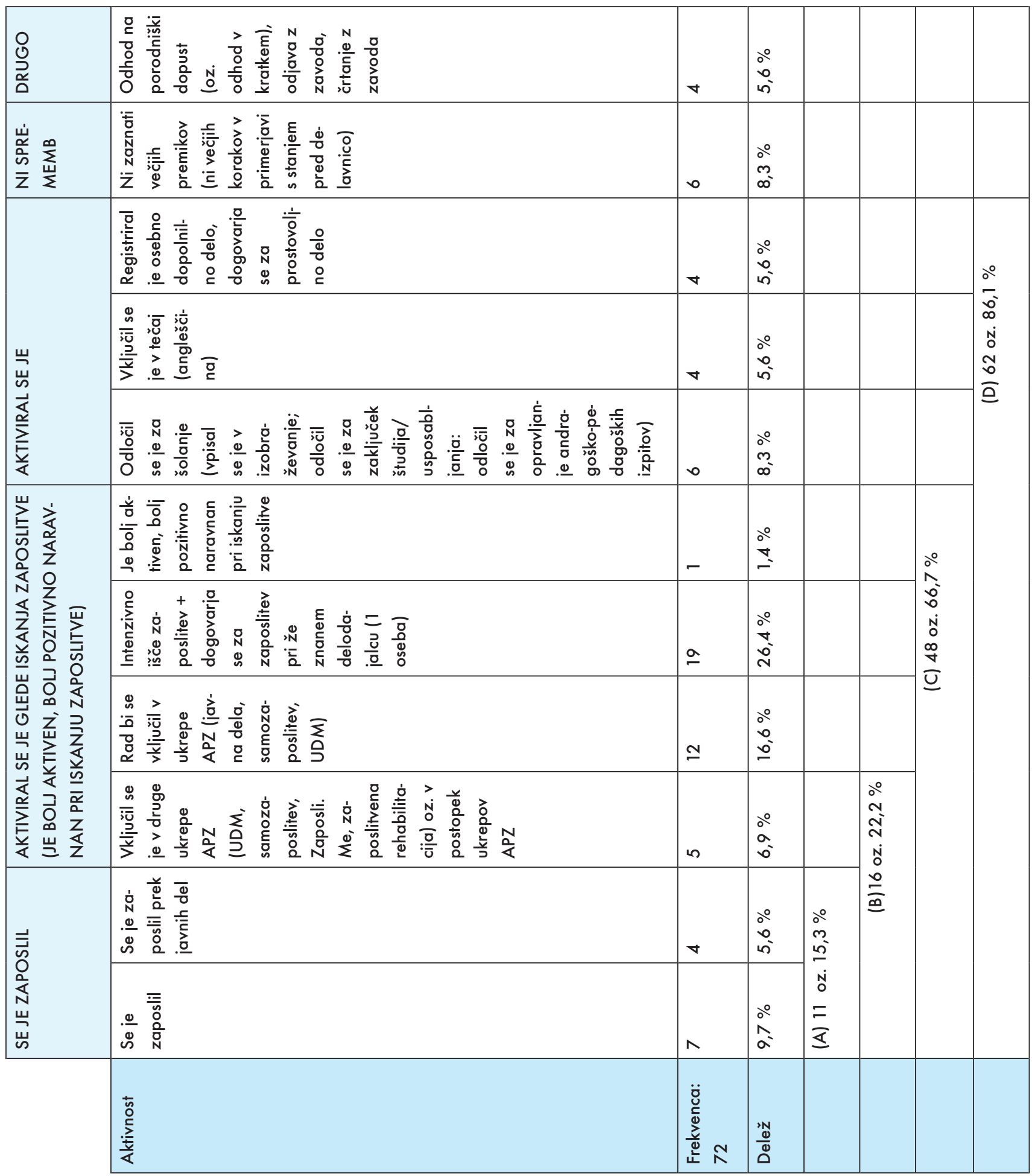


dokončanje šolanja in vključitev $\mathrm{v}$ formalne tečaje se je odločilo dobrih osem odsotkov udeležencev; tudi ta kazalec lahko razumemo kot objektivno merilo uspešnosti delavnice. Če ta dva deleža združimo $(22 \%+8 \%)$, dobimo 30,5 odstotka, kar je slaba tretjina udeležencev. Če temu prištejemo še udeležence, ki bi se radi vključili v ukrepe APZ (so se že prijavili, a postopki še niso speljani, slabih 17 odstotkov), dobimo 47 odstotkov; slaba polovica udeležencev se je aktivirala objektivno merljivo.

Vsi zgoraj navedeni deleži so razmeroma veliki.

Podatek o aktivaciji pri iskanju zaposlitve (intenzivno išče zaposlitev, je bolj aktiven, bolj pozitivno naravnan pri iskanju zaposlitve) ni tako objektiven kot zgoraj navedeni, je pa vseeno zgovoren; zaposlitev po udeležbi na delavnici intenzivno išče dobrih 26 odstotkov oseb. Del teh oseb je zaposlitev po vsej verjetnosti intenzivno iskal tudi pred delavnico, jih je pa po vsej verjetnosti delavnica v tem smislu spodbudila kar nekaj. Dobri dve tretjini udeležencev (66,7 odstotka) (C) stase skozi delavnico aktivirali neposredno v smislu reševanja situacije nezaposlenosti.

$\mathrm{V}$ času delavnice se je tako ali drugače aktiviralo 86 odstotkov (D) udeležencev. Udeležba na delavnici ni prinesla sprememb pri dobrih osmih odstotkih udeležencev, kar je razmeroma majhen delež.

Delavnica Drugače je tudi po rezultatih dobra delavnica - dosega zelo dobre rezultate $\mathrm{v}$ smislu pomoči/spodbude vključenim dolgotrajno brezposelnim osebam pri reševanju njihove situacije brezposelnosti.

\section{ZAKLJUČEK}

Delavnica »Če želim, da bi bilo drugače, moram nekaj spremeniti « v delo s strankami zavoda za zaposlovanje vpeljuje nekatere novejše koncepte in pristope. Njen namen je (dolgotrajno) brezposelnim osebam pomagati pri reševanju njihove nezaželene situacije brezposelnosti.

Delavnica je primerna za osebe obeh spolov, vseh starosti, izobrazbenih stopenj in časa prijavljenosti na zavodu. Dobro je sprejeta tako med udeleženci kot tudi moderatorji. Oboji jo ocenjujejo kot potrebno in zaželeno. Čeprav je udeležba prostovoljna - ali pa ravno zato - se zanjo odloči zelo velik delež vabljenih na predstavitveno srečanje; velika večina jih nato delavnico obiskuje do konca. Udeleženci se je radi udeležujejo. Všeč jim je, da je udeležba prostovoljna, da ni prisile. Uporabljene vsebine, vaje in metode se jim zdijo primerne; ne samo to, ocenjujejo jih kot potrebne in učinkovite.

Všeč jim je, da lahko govorijo o sebi in svoji situaciji, da izmenjujejo poglede, izkušnje in informacije. Všeč jim je, da moderatorji z njimi vzpostavijo odnos enakopravnosti in enakovrednosti.

Delavnica je razmeroma zelo učinkovita; večina udeležencev se $\mathrm{v}$ času delavnice in po njej tako ali drugače samoaktivira. Pri precejšnjem deležu udeležencev sproža spremembe oz. premike, ki jim pomagajo pri reševanju njihove situacije (dolgotrajne) brezposelnosti. Te premike tudi manifestirajo oz. udejanjajo. Če razmere na gospodarskem/zaposlitvenem področju trenutno ne bi bile tako slabe, bi se po vsej verjetnosti zaposlilo še več udeležencev.

Čeprav je delavnica Drugače oblikovana za stranke zavoda za zaposlovanje, so uporabljene tehnike in metode primerne tudi za druge skupine prebivalstva. 


\section{LITERATURA}

Amundson, N. E. (2009). Active Engagement; The being and doing of career counselling. Richmond:ErgonCommunications.

Braden, G. (2010). Božanska matrika; most, ki povezuje čas, prostor, čudeže in prepričanja. Ljubljana: Cangura.

Gútlinger, E. (2011). Easy, Mit Leichtigkeit das Abenteuer leben gestalten. Sthaler: Ennsthaler Verlag.

Imbimbo, P. V. (1994). »Integrating personal and caree rcounselling. A challenge for counselors $«$. Journal of Employment Counseling, 31, 50-59.

Liptak, J. J. (december 2005). »Using emotional intelligence to help college students succeed in the workplace«. Journal of employment counselling, 42: 171-178.

Meadows, K. (2003). Shamanic Experience; A Practical Guide to Psychic Powers. Rochester: Bear \& Company.

McGraw, P.C. (2002). Življenjske strategije; kako se odločati, obnašati in živeti učinkovito. Ljubljana: Orbis.

McTaggart, L. (2004). Polje: po sledi nevidnih silv vesolju. Ljubljana: Ara.

Miller, W. R.,Rollnick, S. (2002). Motivational Interviewing; preparing people forchange. New York, London: The Guilford press.

Parfitt, W. (1997). Prvine psihosinteze. Ljubljana: Aura. Pink, D. H. (2011). Zagon: presenetljiva resnica o tistem, kar nas dejansko motivira. Maribor: Videotop.

Ruppert, J. J. (2010b). Does guidance really matter. Luxembourg: LCD Mersch in Centre de psychologie et d'orientation scolaires (neobjavljeno).

Ruppert, J. J. (2010c). Proposing emancipatory model for VC. Luxembourg: LCD Mersch in Centre de psychologie et d'orientation scolaires (neobjavljeno).

Schwarz, A. A.,Schweppe, R. P. (2005). Moč podzavesti:nevrolingvistično programiranje. Ljubljana: Mladinska knjiga.

Slavinski, Ž. M. (2009). PEAT in nevtralizacija prvinskih polarnosti. Brežice: Primus.

Sultana, R. (2012). Learning by comparing; forming career guidance practitioners in Europe (interno gradivo v sklopu projekta Enotna vstopna točka za karierno orientacijo). Ljubljana: ZRSZ.

Wilks, F. (2009). Inteligentna čustva: čustva - kako jih prepoznati, razumeti in harmnonizirati. Kranj: Ganě̌.

Zimbardo, P. G., Boyd, J. (2009). The time paradox: the new psychology of time that will change your life. New York: Free Press.
1. Za popolno objektivizacijo te trditve bi bilo sicer treba izvesti primerjalno študijo/poskus, ko udeležba na isti delavnici ne bi bila prostovoljna, tj. napotitev s sankcijami za neudeležbo, ali vsaj primerjalno analizo udeležbe na kakšni drugi delavnici zavoda, kamor so potencialni udeleženci napoteni pod grožnjo sankcij za neudeležbo. Na podlagi izkušenj je ocena, da je delež udeležbe na delavnici Drugače vsaj tako velik kot na »obveznih«, zelo verjetno pa je večji, realna. 